\title{
Gasoline sensor based on ZnO
}

\author{
M.S. Aleksanyan ${ }^{1}$, V.M. Arakelyan ${ }^{1}$, V.M. Aroutiounian ${ }^{1 *}$, A.G. Sayunts ${ }^{1}$ \\ 1 Yerevan State University, 1 Alek Manookian St., 0025 Yerevan, Armenia, \\ "Corresponding author: 1 Alek Manookian St., 0025 Yerevan, Armenia; e-mail: \\ aroutiounv1@yahoo.com; phone: +37460710311; fax: +37460710355
}

\begin{abstract}
$\mathrm{ZnO}+1$ at.\%La gas sensitive thin films with different thicknesses were deposited on alumina substrate by the rf magnetron sputtering method using $\mathrm{ZnO}+1$ at.\%La ceramic target prepared by us. Palladium catalytic particles and interdigited titanium contacts were deposited by ion beam sputtering method on the surface of the sensing layers. The response of semiconductor films to gasoline, toluene and dichlorethan vapors was measured at different operating temperature to 1000 and 2000 ppm gasoline vapor concentration. It was found that the La-doped $\mathrm{ZnO}$ sensor with film thickness of $80 \mathrm{~nm}$ exhibits high response (120) and selectivity to gasoline vapor (at operating temperature of $350{ }^{\circ} \mathrm{C}$ and 2000 ppm gasoline vapor concentration).
\end{abstract}

Key words: thin film, magnetron sputtering, gasoline, $\mathrm{ZnO}$, gas sensor

\section{Introduction}

$\mathrm{ZnO}$ is a wide band gap $(3.37 \mathrm{eV})$ semiconductor. Due to its high thermal and chemical stability it is widely used in solar cells, optoelectronic devices, semiconductor resistive gas sensors and etc [1-5].

Zinc oxide as a gas sensing material is used in semiconductor gas sensor made of: resistive thin film with nanosized grains, nanowires, nanofibers, nanotubes and so on. Such sensors exhibit high sensitivity to various gases $\left(\mathrm{H}_{2}, \mathrm{NO}\right.$, alcohol, gasoline, toluene, dichlorethan vapors and etc) [6-10].

As we know, gasoline is used in various fields. Especially, it is widely used as a fuel. Cars need in the gasoline high response and selectivity sensors. They should fast detect the gasoline leakage. High precision control of the air-fuel ratio in vapor control system of car engine is necessary [11,12]. There are fuel level non-semiconductor sensors produced by Dongguan Manufacturer, etc. They are complicated, it is necessary to develop microelectronic semiconductor sensors.

It is known that the key parameters of resistive thin film gas sensors depend on the thickness of a sensing layer. Especially, the increase in the response of thin film sensor with decreasing of the sensing layer thickness was observed. Beside, there is an opposite dependence (an increase in the response on the thickness) [13-20]. As we shown below, the first dependence is typical for our samples.
Resistive thin film gas sensors with derrerent thicknesses made of the $\mathrm{ZnO}+1$ at\%La structure with nanosized grains were prepared by us. The thin film sensor with the film thickness of $80 \mathrm{~nm}$ has enhanced response and selectivity to gasoline vapor.

\section{Experimental}

$\mathrm{ZnO}$-based gas sensing films were deposited by magnetron sputtering method from previously prepared ceramic target. Metal oxide starting materials (powders) were weighted in appropriate quantities ( $\mathrm{ZnO}+1$ at.\%La) and mixed for approximately 10 hours. Then, this mixture was subjected to preliminary heat treatment in the $800^{\circ} \mathrm{C}-1100^{\circ} \mathrm{C}$ temperature range. The resulting mixture was pressed (using the $2000 \mathrm{~N} / \mathrm{cm}^{2}$ pressure) in a form of the $50 \mathrm{~mm}$ diameter tablet and annealed. Annealing was performed in software controlled furnace (Nabertherm, HT 04/16) at different temperatures $\left(1000^{\circ} \mathrm{C}-1400^{\circ} \mathrm{C}\right)$. Then, the sample was subjected to mechanical treatment in order to eliminate surface defects and obtain the smooth, parallel target with the appropriate thickness $(<2 \mathrm{~mm})$ and diameter $(40 \mathrm{~mm})$. The $\mathrm{ZnO}+1$ at.\%La gas sensitive thin films with derrerent thichnesses were deposited on alumina substrate by the rf magnetron sputtering method using obtained $\mathrm{ZnO}+1$ at.\% $\mathrm{La}$ ceramic target. The growing film thickness was cntroled by the changeing of the sputtering time when the power of the magnetron generator unit was fixed. The sputtering duration equals to $10,15,30,45$ minutes and the power of 
magnetron generator unit was $60 \mathrm{~W}$. The substrate temperature during sputtering was $200{ }^{\circ} \mathrm{C}$. Palladium (Pd) catalytic particles (the deposition time was 2 seconds) and interdigited titanium ( $\mathrm{Ti}$ ) contacts (the deposition time was 50 minutes) were deposited by ion beam sputtering method on the surface of the sensing layers. The obtained thin film with sputtering duration of 10 minutes was enough thin (the layer was not continuous) and had an extremely high electrical resistance $\left(10^{12} \mathrm{ohm}\right)$. The film with sputtering duration of 45 minutes was enough thick $(400 \mathrm{~nm})$ and exhibited poor sensitivity to gasoline, toluene and dichlorethan vapors. So, here only the sensing results of the thin films with sputtering duration of 15 and 30 minutes are presented.

\section{Results and discussion}

The thicknesses of the $\mathrm{ZnO}+1$ at.\%La films with sputtering duration of 15 and 30 minutes were measured by Ambios XP-1 profilometer wich are 80 and $210 \mathrm{~nm}$ respectively (see Fig. 1).

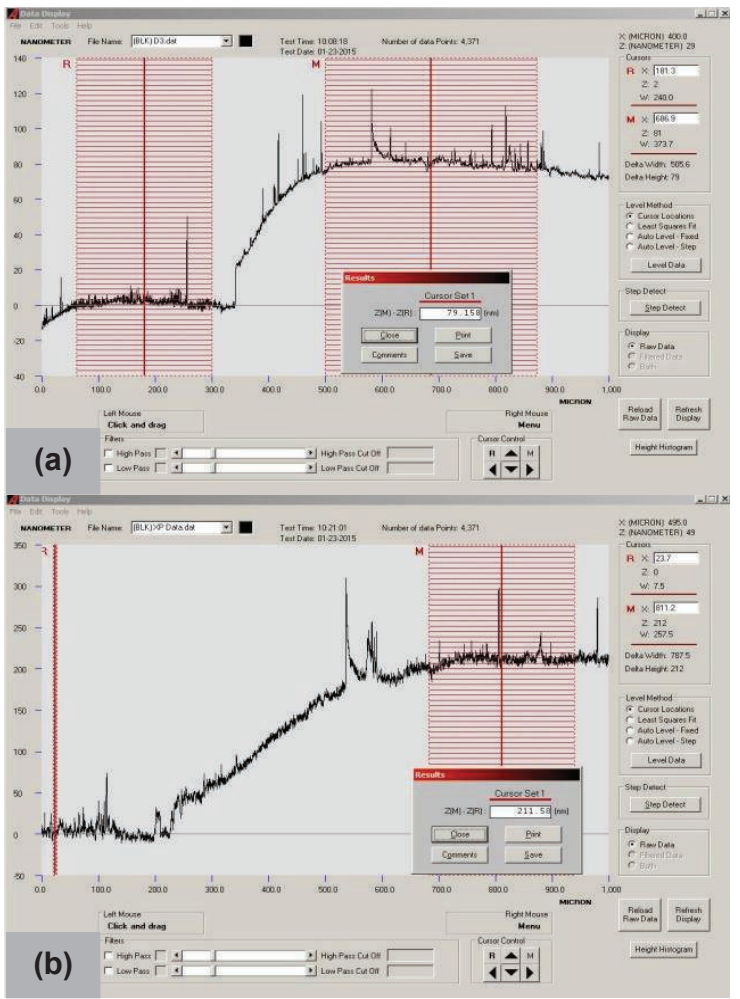

Fig. 1. The ZnO+1at.\%La films thichnesses measurament resultes with sputtering duration of 15 (a) and 30 minutes (b)

The response (the ratio of the resistance of the sample in air to the resistance in gasoline vapor, $\left.\mathrm{R}_{\text {air }} / \mathrm{R}_{\text {gas }}\right)$ of the semiconductor $\mathrm{ZnO}+1$ at.\% La sensors to gasoline, toluene and dichlorethan vapors were measured in different temperature range of the work body by gas measurement system [21]. The corresponding responses for the two sensing layers with different thicknesses are presented in Fig. 2. The thinner $(80 \mathrm{~nm}) \mathrm{ZnO}+1$ at.\%La based structure exhibits better response to gasoline vapor. The reduction of the sensing layer thickness enhances the sensor response more then four time.

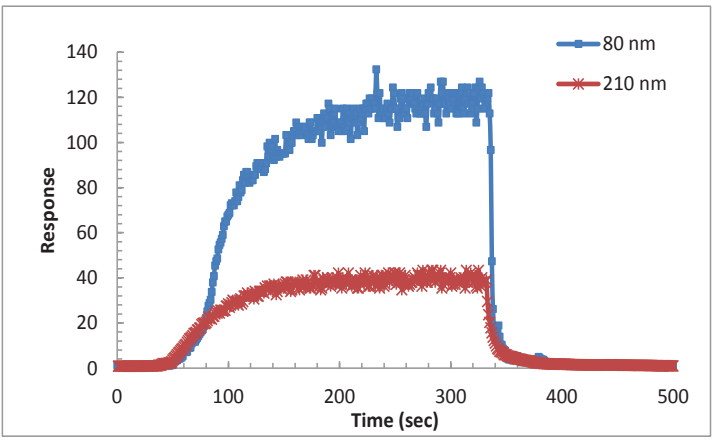

Fig. 2. The response curves of the $\mathrm{ZnO}+1 \mathrm{at} \% \mathrm{La}$ sensors (with thicknesses of 80 and $210 \mathrm{~nm}$ ) to $2000 \mathrm{ppm}$ gasoline vapor concentration (the work body temperature was $350^{\circ} \mathrm{C}$.)

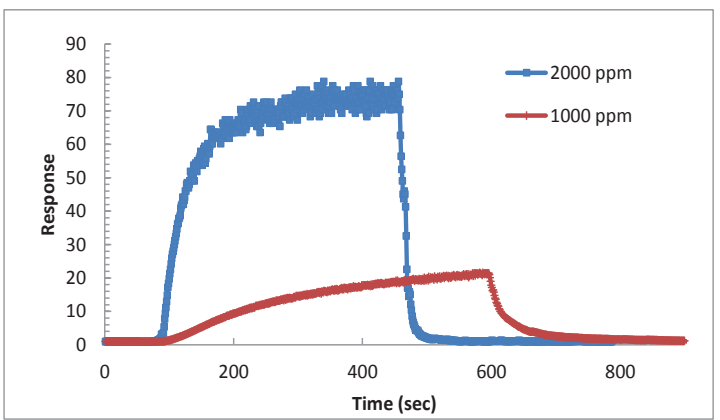

Fig. 3. The real-time response curves of the $\mathrm{ZnO}+1 \mathrm{at} . \% \mathrm{La}$ sensors (with thickness of $80 \mathrm{~nm}$ ) to various concentration of gasoline vapor (the work body temperature was $300^{\circ} \mathrm{C}$.)

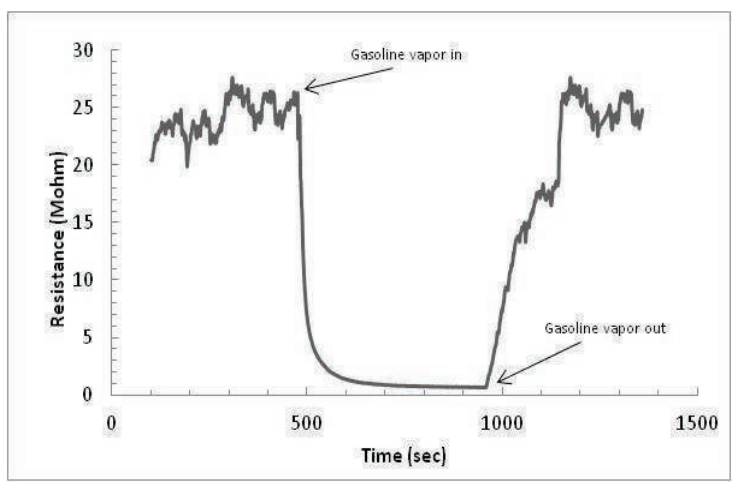

Fig. 4. The variation of the resistance of the ZnO+1at.\%La sensor (with thickness of $80 \mathrm{~nm}$ ) for 1000 ppm gasoline vapor concentration (the work body temperature was $350^{\circ} \mathrm{C}$.)

The response of the $\mathrm{ZnO}+1$ at.\%La film to different concentration of gasoline vapor is shown in Fig. 3. The response of the sensor increases rapidly with increasing in the concentration of gasoline vapor. It is also clear 
that both the response and recovery times improve with increasing in gasoline vapor concentration.

Fig. 4 shows the resistance change of the $\mathrm{ZnO}+1$ at.\%La sensor in the presence of 1000 $\mathrm{ppm}$ gasoline vapor concentration. It is clear that the response and recovery times are 30 and $130 \mathrm{~s}$. respectively.

The variation of response of the $\mathrm{ZnO}+1$ at.\%La sensors as a function of work body temperature is shown in Fig. 5. The sensitivity increase with the work body temperature increasing was also observed. The plots indicate that there is an approximately linear relation between the response of the La-doped $\mathrm{ZnO}$ sensors and the work body temperature for both 80 and $210 \mathrm{~nm}$ thicknesses of sensing layers.

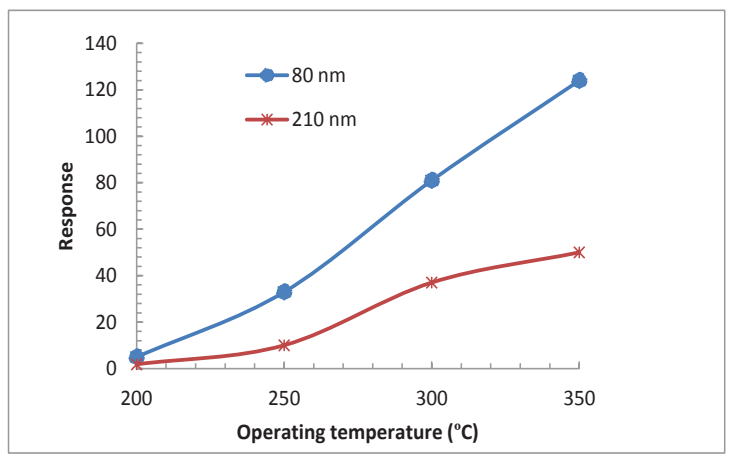

Fig.5. The relationship of the $\mathrm{ZnO}+1 \mathrm{at} . \% \mathrm{La}$ sensors response and operating temperature for 2000 ppm gasoline vapor concentration.

It is know that the poor selectivity is serious problem for the practical useable gas sensors. The selectivity of the La-doped $\mathrm{ZnO}$ sensor (with thickness of $80 \mathrm{~nm}$ ) toward other gases such as toluene and dichlorethane vapors was also investigated. The sensor exhibits high selectivity toward gasoline vapor at different work body temperatures (see Fig.6).

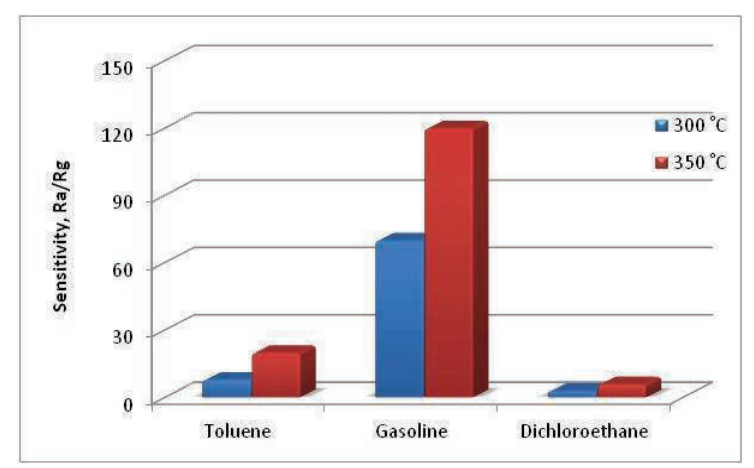

Fig. 6. The sensitivity and selectivity of the ZnO+1at.\%La sensor to different gases (2000 ppm concentration) at different work body temperatures.

\section{Conclusion}

The La-doped $\mathrm{ZnO}$ sensitive thin films with different thichnesses were fabricated by the rf magnetron sputtering technology. The response and selectivity behaviors of the $\mathrm{ZnO}+1$ at.\%La sensors were investigated. The sensing results indicated that the response of the gas sensor with $80 \mathrm{~nm}$ thickness is higher then that of 210 $\mathrm{nm}$. The $\mathrm{ZnO}$ based sensor (with $80 \mathrm{~nm}$ thickness) exhibits high sensitivity (120) and selectivity to small concentration of gasoline vapor. The response and recovery properties of the sensor are also appreciable. Therefore, it can successfully serve as gasoline vapor detector.

\section{Acknowledgements}

Investigations were carried out in framework of NATO SfP-EAP.SFPP 984597 and State Committee of Science MES RA 13-1C075 projects. Authors express gratitude to Dr. V. Kuzanyan for help in the measurements of thickness of our samples.

\section{References}

[1] J. Xu, J. Han, Y. Zhang, Y. Sun, B. Xie, Studies on alcohol sensing mechanism of $\mathrm{ZnO}$ based gas sensors, Sensors and Actuators B 132, 334-339 (2008); doi: 10.1016/j.snb.2008.01.062

[2] A.I. Uddin, D.T. Phan, G.S. Chung, Low temperature acetylene gas sensor based on $\mathrm{Ag}$ nanoparticles loaded $\mathrm{ZnO}$-reduced graphene oxide hybrid, Sensors and Actuators B 207, 362369 (2015); doi: 10.1016/j.snb.2014.10.091

[3] N. Hsu, M. Chang, C. Lin, Synthesis of ZnO thin films and their application as humidity sensors, Microsyst Technol 19, 1737-1743 (2013); doi: 10.1007/s00542-013-1830-z

[4] K. S. Venkatesh, K. Vijayalakshmi, K. Karthick, S. R. Krishnamoorthi, N. S. Palani, R. Ilangovan, Fabrication of room temperature $\mathrm{H}_{2}$ gas sensor using pure and $\mathrm{La}: \mathrm{ZnO}$ with novel nanocorn morphology prepared by sol-gel dip coating method, J Mater Sci: Mater Electron 25, 4339_ 4347 (2014); doi: 10.1007/s10854-014-2171-0

[5] J. Saydi, M. Karimi, M. Mazhdi, J. Seidi, and F. Mazhdi, Synthesis, Characterization, and Gas Sensing Properties of Pure and Mn-doped $\mathrm{ZnO}$ Nanocrystalline Particles, JMEPEG 23, 34893496 (2014); doi: 10.1007/s11665-014-1162-x

[6] C.S. Prajapati, P.P. Sahay, Alcohol-sensing characteristics of spray deposited $\mathrm{ZnO}$ nanoparticle thin films, Sensors and Actuators B 160, 1043-1049 (2011); doi: 10.1016/j.snb.2011.09.023

[7] G. Zhu, H. Xu, Y. Liu, X. Xu, Zh. Ji, X. Shen, $\mathrm{Zh} . \mathrm{Xu}$, Enhanced gas sensing performance of Co-doped $\mathrm{ZnO}$ hierarchical microspheres to 1.2dichloroethane, Sensosr and Actuators B 166- 
167, 36-43 (2012)

doi: 10.1016/j.snb.2011.11.048

[8] Y. Zeng, T. Zhang, L. Wang, M. Kang, H. Fan, R. Wang, Y. He, Enhanced toluene sensing characteristics of $\mathrm{TiO}_{2}$-doped flowerlike $\mathrm{ZnO}$ nanostaractures, Sensors and Actuators B 140, 73-78 (2009); doi: 10.1016/j.snb.2009.03.071

[9] H. Wang, C. Zou, C. Tian, L. Zhou, Z. Wang and D. Fu, A novel gas ionization sensor using Pd nanoparticle-capped $\mathrm{ZnO}$, Nanoscale Research Letters 6, 534-538 (2011); doi: 10.1186/1556276X-6-534

[10] Y. Zong, Y. Cao, D. Jia, P. Hu , The enhanced gas sensing behavior of porous nanocrystalline $\mathrm{SnO}_{2}$ prepared by solid-state chemical reaction, Sensors and Actuators B 145, 84-88 (2010); doi: 10.1016/j.snb.2009.11.026

[11] H. Fan, X. Jia, Selective detection of acetone and gasoline by temperature modulation in zinc oxide nanosheets sensors, Solid State lonics 192, 688692 (2011); doi: 10.1016/j.ssi.2010.05.058

[12] A.S. Poghossian, H.V. Abovian, V. M. Aroutiounian, Selective petrol vapour sensor based on an $\mathrm{Fe}_{2} \mathrm{O}_{3}$ thin film, Sensors and Actuators B 18, 155-157 (1994); doi: 10.1016/0925-4005(94)87075-6

[13] J. Liu, J. Han, S. Gong, J. Xia, L. Quan, H. Liu, D. Zhou, The sensor response of tin oxide thin films to different gas concentration and modification of the gas diffusion theory, Sensors and Actuators B 138, 289-295 (2009); doi: 10.1016/j.snb.2009.02.018

[14] G. Korotcenkov, M. Ivanov, I. Blinov, J.R. Stetter, Kinetics of indium oxide-based thin film gas sensor response: The role of "redox" and adsorption/desorption processes in gas sensing effects, Thin Solid Films 515, 3987-3996 (2007); doi: 10.1016/j.tsf.2006.09.044

[15] D. Haridas, V. Gupta, Enhanced response characteristics of $\mathrm{SnO}_{2}$ thin film based sensors loaded with $\mathrm{Pd}$ clusters for methane detection, Sensors and Actuators B 166-167, 156-164 (2012); doi: 10.1016/j.snb.2012.02.026

[16] N.M. Vuong, N.M. Hieu, H.N. Hieu, H. Yi, D. Kim, Y.S. Han, M. Kim, $\mathrm{Ni}_{2} \mathrm{O}_{3}$-decorate $\mathrm{SnO}_{2}$ particle films for methane gas sensors, Sensors and Actuators B 192, 327-333 (2014); doi: 10.1016/j.snb.2013.10.117

[17] S. Gong, J. Liu, J. Xia, L. Quan, H. Liu, D. Zhou , Gas sensing characteristics of $\mathrm{SnO}_{2}$ thin films and analyses of sensor response by the gas diffusion theory, Materials Science and Engineering B 164, 85-90 (2009); doi: 10.1016/j.mseb.2009.07.008

[18] D. Haridas, V. Gupta, Study of collective efforts of catalytic activity and photoactivation to enhance room temperature response of $\mathrm{SnO}_{2}$ thin film sensor for methane, Sensors and Actuators $B$ 182, 741-746 (2013); doi: 10.1016/j.snb.2013.03.100
[19] V. M. Aroutiounian, Porous silicon gas sensors, Semiconductor Gas Sensors, Chapter 12, 408430 (2013); doi: 10.1533/9780857098665.3.408

[20] V. M. Aroutiounian, A.Z. Adamyan, E.A. Khachaturyan, Z.N. Adamyan, K. Hernadi, Z. Pallai, Z. Nemeth, L. Forro, A. Magrez, E. Horvath, Study of the surface-ruthenated $\mathrm{SnO}_{2} / \mathrm{MWCNT}$ nanocomposite thick- film gas semsors, Sensors and Actuators B 177, 308-315 (2013); doi: 10.1016/j.snb.2012.10.106

[21] V.M. Aroutiounian, V.M. Arakelyan, E.A Khachaturyan, G.E. Shahnazaryan, M.S. Aleksanyan, L. Forro, A. Magrez, K. Hernadi, Z. Nemeth, Manufacturing and investigations of $\mathrm{i}$-butane sensor made of $\mathrm{SnO}_{2} /$ multiwall-carbon-nanotube nanocomposite, Sensors and Actuators B 173, 890-896 (2012); doi: 10.1016/j.snb.2012.04.039 